\title{
Problems of Translating Culture-Specific Terms, Realies Which Existed In the Uzbek
}

\section{Language}

\author{
Niyozova Shoira Tairovna ${ }^{a}$, Khalikova Dildora Yadullaevna ${ }^{b}$ and Kadirova Dilnoza Mamadiyorovna ${ }^{c}$ \\ ${ }^{\text {a,b,c }}$ English Teacher, Navoi State Pedagogical Institute, Uzbekistan
}

Article History: Received: 11 January 2021; Accepted: 27 February 2021; Published online: 5 April 2021

\begin{abstract}
The article covers a broad range of culture-bound words, realia translation, the identification of the main types and difficulties of translation based on the material of literary works translated from Uzbek into English. There was analyzed the presentation of national and historical realias and national features, problems of similarity and equivalency in translated artistic composition.
\end{abstract}

Key words: equivalent, transcription, explanation, nation, literary work, national features, literature, to convey

\section{INTRODUCTION}

The development of intercultural and international relationship gives the opportunity to be acquainted with literature and culture world. Especially, the fame question of our culture through translated artistic compositions is essential. Nowadays translating national and historical realias is in the high level. Culturebound words are culturally loaded words borrowed from another language due to language contacts. Among the objective difficulties of the works of Uzbek writer translation into the English language, one can note the mismatch of Uzbek, Russian and English words or phrases expressing realities. It is especially difficult to translate those words and expressions that are close in meaning, but differ in "volume". According to Newmark: "Translation is a craft consisting in the attempt to replace a written message and/or statement in one language by the same message and/or statement in another language" (Newmark, 1981:7) But, with culturally-bound words this is often impossible. Definitely, the meaning which lies behind this kind of expressions is always strongly linked to the specific cultural context where the text originates or with the cultural context it goals to re-create.

\section{MATERIALS AND METHODS.}

Translator considers the translation of realias to be an interesting as well as difficult work, because insufficient awareness of history social order, culture, traditions, political life can result in inadequate translation which can fail to be perceived by the recipient or be perceived in a wrong way. Such a situation can occur because realias are the words, which may convey the cultural identity of the native-speaking population. The peculiarities of the culture may be unknown to the definite people from another country so the translator is that very person who is responsible for the 'clear' translation.

The use of realia is common place in the ESL/EFL classroom and is widely considered to have great value in fostering an active teaching-learning environment. It provides the learners a meaningful learning experience as it connects the classroom activities to the real world. It also provides some suggestions on how to choose realia appropriately for classroom activities to ensure effective learning. Using realia can make the learning process meaningful and more memorable for the learners as they can connect it with their real life; thus, adding a new dimension in the language learning process. They feel motivated and get involved with the learning process as they can apply their knowledge in everyday situations.

The term realia refers to a local word or phrase that does not translate because there is no obvious equivalent in the target language - and there are several strategies for handling them.

There are a few basic ways to handle realia and troublesome idioms:

Transcription: You can simply copy the realia exactly as it appears, perhaps with an explanatory note. This can suffice, although it's not the best solution as it pushes the work off onto the reader.

Explanation: You can try to create an explanatory translation that maintains the overall structure of the speech while getting the point across. This is often clumsy.

Equivalency: You can try to find something similar in the target language. Sometimes this works and sometimes it doesn't, and you have to be careful that you know the local stories behind the realia and the substitute well enough to judge that they convey exactly the same meaning.

Importantly, the differences between cultures require the translator to have a deep linguistic knowledge as well as an awareness of the cultures of the peoples. For example, Uzbek cultural norms are undoubtedly different from British, Arabian culture. Some words or sentences found in our national works create a pragmatic situation in the text that is unique to our nation. In order to understand these subtleties, it is necessary to be a representative of the Uzbek nation. Our personal preference is to transcribe 
the realia without translation. Context usually serves to explain it, and if nothing else this marks the word or phrase as untranslatable, sparking research. In the end, the goal of translation is accuracy, and this may be the only reliable way to ensure that.

Culturally-bound expressions: are terms and expressions such as idioms, collocations, metaphors, and proverbs that are specific to a certain culture and embedded in different types of texts i.e. social, religious, political, and geographical.

By comparing several languages, we may distinguish regional realias and international, existing in the lexicon of many languages, which entered the vocabulary though preserving their initial colour. Translation of the realia demands the translator to be especially careful. Although we mean the notions and objects which may be accurately described and defined, while translating them into the target language there may occur remarkable deviations and variations. It is connected with the fact that by the frequency of use, by the role in the language, by the household meaning, the words naming the realias do not have any term colouring. To translate the realia in a correct way it is necessary to take into account the following factors;

-the type of the text,

- the meaning of the realia in the text,

- the type of the realia and its systematic role in the culture of the source language,

-the degree of perception of the unusual word-collocations.

In translation, it is important to keep the author's intention and attitude. On this base, the main problem in translation is realia. Realia is the thought which is connected with country, the history of nation, culture and life. In literary compositions the realia is used for showing the being, cultural life, and the feature of a nation. We can involve words, word combinations, even proverbs, aphorisms, poetic words that can strengthen the socio-historic or the nation-cultural portray of the nation. We also tried to find some regional realies from Uzbek writes' literary works and give definitions, create an explanatory translation. Before translating, it is necessary to check whether a loan word exists in the target language, whether its meaning corresponds to that of the source language word, and what its phonetic and graphic form is (care should be taken for the different spellings of a source language word and the loan word, like lunсh-ленч). [3, p119]

\section{COMPARATIVE ANALYSIS OF ENGLISH AND UZBEK REALIES}

What is most important in translating culture-bound words is the receptor's perception and reaction. A translator should be aware of the receptor's potential problems and, taking into account the receptor's background knowledge, choose the best means of translation. [3, p 119]

The cultural word translation problems are largely caused by some wrong ideas and interpretations. The failure of transferring the cultural words to the target language can make some disadvantages for the target readers. One of them is cultural misunderstandings. It occurs when the translator uses a wrong procedure in translating a word into the target language culture. The target readers will not receive the same message as the message in the target text if the cultural misunderstanding is found in a translation text. Thus, we can know how a word can mean differently and avoid misunderstanding of the message. Cultural word translation analysis especially in conducting translation procedures must be done to reduce cultural misunderstandings.

Birpasdan keyin qaddimni rostlab, tanchaga oyog 'imni tiqib o'tirdim. Hoji buvi allaqanday taxir suyuqlik ichirdi. [4, p 20]

After a while, I stretched my legs to the 'tancha.' Hoji buvi made me drink something strange bitter liquid.

(Sandal, tancha - local heating medium. It has long been used in Central Asia, Afghanistan, Iran, Turkey, Japan and other Eastern countries. For sandals, a hole is dug in one side of the room, and the inside is specially shaped and plastered. It is equipped with table and covered with a blanket. It is heated with charcoal or wood.)

There is national originality reflected in the literature and other fields of social science and it has the more significance the more it is rich in content, progressiveness, brightness: other nations are enriched meeting with it discovering something new, interesting, useful and important for them in this specific character

Nima uchundir onam tez-tez tolqon qilardi. Sababini keyin tushunganman.

Non ko'pligi uchun emas, kamligi uchun tolqon qilisharkan. [4, p 21]

I wander why my mom often prepared tolqon. Later, I realized the reason of preparing it. I found out that my parents could not supply members of our family with bread.

(Tolqon - type of food. It is made from corn, wheat, oats, bread and fruit. Method of preparation: roasted grain, dried bread or fruit crumbs, crush them with mixer. You can add some sugar, if you want.)

Translators need to find the mostly used culture bound word is material culture and the mostly used translation procedure is culture equivalence. From the connection among cultural word and procedures analysis, we, translators can conclude that every cultural word class requires different translation procedure. 
Chimildiq - muqaddas joy. Unga xiyonat qilishni hayolingizga ham keltirmang.

Chimildik is a sacred place for you. Don't think about betraying. Chimildik. Uzb. chimildiq and po'pak the same popuk - fringe] A fringed curtain used in marriage ceremony

Cultural issues may arise from differences between cultural references, such as names of food, festivals and cultural connotations, in general. The translator will use language localization to correctly adapt the translation to the culture targeted.

Supadagi xontaxta oldiga borib o'tirdim. Dasturxonda to'nkarib qolgan ikkita piyola bilan choynakdan bolak narsa yo'q edi. [4, p 22]

I came and sat at the xontaxta. There were only a tea pot and two cups on it.

(Xontaxta - household item; the form of the low table may be rectangular or circular. It is used as a kitchen table. It is also called "low table".)

Any literary work appears on the national ground, reflects national interest, problems, and features. Passing from one nation to another literature enriches and extends the notion of peoples about each other. It is one of the most difficult cases to convey national coloring. Owing to the translation, very important literary works were able to appear in many other countries and became available for people speaking other languages. The translation helps mutual knowing and peoples' enrichment.

Insofli odamlar bevaga choyxona yonboshidagi pastak hujrani ajratib berishgan.

Honest people in the village gave a small house to the widow near the choyxona. $[4, \mathrm{p} 36]$

"Choyxona" The teahouse is a public cafeteria designed primarily for drinking tea. Widespread in Central Asian countries, Iran and Turkey. Alcohol drinks are not sold there.)

- Kechqurun o'sma ezib qo’yuvdim. Shu savil qurib qolmasin, deb qoshimga qo'ya qoluvdim.

In the evening, I squeezed some tumor (usma). In order not to spoil it, I polished it on my eyebrows.

(O'sma -it is one of the types of plant, which grow especially in Central Asia, Uzbek women can use it by squeezing its leaves and rub them on their eyebrows and eyelash for decoration and for treatment.)

Spreading of national culture confines with the help of translation has a great positive and enriching influence on the language. It is true that together with the translation many new ideas, discoveries, notions and so on penetrate in the language and it leads to the appearance of new language elements and figurative meanings. This fact is very important while translating from literary language that is not fully developed. The literary language enriches figurative possibilities, national culture, and spiritual development of this nation. Creative beginning of translation is premise of creative attitude to native language, its source of faith in its possibilities and beauty. Geographical features can be normally distinguished from other cultural terms in that they are usually value-free, politically and commercially. Nevertheless, their diffusion depends on the importance of their country of origin as well as their degree of specificity.

tushdiyu, ko'rmaslikka oldi.

$$
\mathrm{U} \text { tusatdan bir guruh } \underline{\text { chilim }} \text { chekib turgan yigitlarga ko'zi }
$$

Suddenly she saw some young men smoking $\underline{\text { chilim }}$, tried pretending not to

see. (Chilim An oriental tobacco pipe with a long, flexible tube that draws the smoke through water contained in a bowl.)

Translating from Uzbek into English translator may meet some difficulties to render some words which mean something in Uzbek but no meaning in English. So, how to deal with this problem. That's a complicated task which must be dealt with. It is necessary to know the culture of both nationalities before translating. By having known the nationality and its culture closely translators may render words in an efficient way.

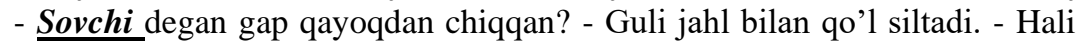
unisi keladi qiyshayib, hali bunisi keladi, tugunini osiltirib! [4, p50]

-Why do we need sovchi?-Guli shook her hands with nervous._I don't need them. But, they are coming, coming, coming without getting permission.

(Sovchi-it may be he or she, who can go to someone's house to ask their daughter for a bride. Usually, uncles, aunts, or one of the relatives are asked to visit there in order to ask agreement for getting married.)

The task of the translator is to find and rail the essence of national peculiarities and specific character. Correct conveying of these nationality elements opens the way to reveal internationality in the work.

- Bu - umr savdosi. - Keyin shisha nosqovog'ini olib, $\underline{\text { nos }}$ otdi. - Qizingni ko'ngliniyam bilish kerak [4, p 54]

-Life is complicated thing.-he put some $\underline{\text { nos }}$ under his tongue, continued his speech-We have to clarify, she agrees or not getting married. 
(Nos- It is made from tobacco. Nos can be put under the tongue after a while to spit it. It is usually used by men.)

Bektemir qo'lbola nosdan bir chimdim til tagiga tashlab, keyin tupurdi. (Oybek, «Quyosh qoraymas» asaridan) Bektemir put some nos under his tongue and after some minutes, he spit it.

When translators managed to convey all the originality of works and these translations became masterpieces as their originals. Originality, national coloring of the work is not lost in the succeed translations and that is one of the main principals of creative translation activity. National coloring like everything in the world is in the constant movement. Here, the translation 's role is enriched with one positive moment. His task is to carry this constantly changing stability to readers of other nations. The task of the translator is defense of the riches and beauty of the native language, its unlimited abilities to convey all that is kept in the greatest masterpieces of world literature.

Ertasiga choydan keyin oyimning $\underline{\text { mahsi }}$ kiyayotganini ko'rib, mehmonga otlanayotganini sezdim-u darrov ergashdim. [4, p 57]

Next morning after the breakfast, I saw my mother wearing mahsi. I guessed that she is going to the quest. I joined her immediately.

(Mahsi- National footwear worn with rubbers or kavushes, ususally made from ram or goat skin, with long tops, without any heels with soft sole.)

4. CONCLUSION AND DISCUSSION. The translator must convey truly both components on this unity keeping in his mind the frequent absence of confines between national and international coloring because they interlace with each other. Translator as creative person who carries works beyond the limits of one national culture and who serves to people giving these fruits of this culture, created in new language form or vice versa, including achievements of other nations in his national science and culture.

Translation process does not only involve two languages but also two different cultures. In bridging those two different things there are some procedures of translation that can be used by the translator. The procedures that are used by the translator in this thesis are the culture equivalence. From the connection among cultural words and translation procedures analysis, we can conclude that every cultural word class requires different translation procedure.

\section{References}

1. Olimova Dilafruzxon. Actual Problems of Literary Translation: Study of Translation Issues from Uzbek into English, Lecturers of National University of Uzbekistan named after Mirzo Ulugbek, 2020.

2. Peter Newmark. A textbook of translation. Shanghai foreign language education press, 1988.

3. Zoya Proshina. Theory of Translation, (English and Russian) Vladivostok Far Eastern University Press, 2008.

4. Hoshimov O'tkir "Dunyoning ishlari” Yangi asr avlodi. Toshkent, 2015 yil 